\title{
Influence of interleukin-1 $\beta$ gene polymorphism on the risk of myocardial infarction complicated with ischemic stroke
}

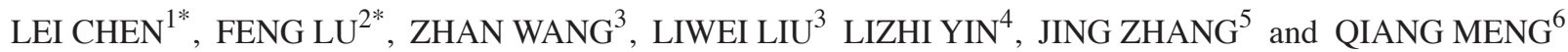 \\ ${ }^{1}$ Department of Cardiothoracic Surgery, The People's Hospital of Zhangqiu District, Jinan, Shandong 250000; \\ ${ }^{2}$ ECG Room, Yantaishan Hospital, Yantai, Shandong 264000; ${ }^{3}$ Endoscopy Center, The Affiliated Central Hospital of \\ Qingdao University, Qingdao, Shandong 266000; ${ }^{4}$ Health Management Center, The People's Hospital of \\ Zhangqiu District, Jinan, Shandong 250000; ${ }^{5}$ Department of Cardiovascular Surgery, The People's Hospital of Rizhao, \\ Rizhao, Shandong 276800; ${ }^{6}$ Ward 2, ICU, Jining No. 1 People's Hospital, Jining \\ Medical University, Jining, Shandong 272100, P.R. China
}

Received April 9, 2018; Accepted September 20, 2018

DOI: $10.3892 / \mathrm{etm} .2018 .6842$

\begin{abstract}
This study investigated the correlation between interleukin (IL)-1 $\beta-511 \mathrm{C} / \mathrm{T}$ gene polymorphism and myocardial infarction (MI) complicated with ischemic stroke (IS). A total of $251 \mathrm{MI}$ patients complicated with IS (observation group) and 200 healthy people (control group) were selected for the case-control study. IL-1 $\beta-511 \mathrm{C} / \mathrm{T}$ gene polymorphism was detected via polymerase chain reaction-restriction fragment length polymorphism (PCR-RFLP). The genotype distribution and allele frequency were compared between the two groups, and the correlation between gene polymorphism and MI complicated with IS, was analyzed after traditional risk factors were adjusted by using logistic regression method. The frequencies of CT and TT genotypes in the observation group were higher than those in the control group $(\mathrm{P}<0.05)$. The frequency of $\mathrm{T}$ allele in the observation group was significantly higher than that in the control group $(\mathrm{P}<0.05)$, but the frequency of $\mathrm{C}$ allele was obviously lower than that in the control group $(\mathrm{P}<0.05)$. According to results of logistic regression analysis, arrhythmia and high-density lipoprotein cholesterol (HDL-C) were associated with MI complicated with IS. In patients with arrhythmia, the risk of disease in carriers with IL-1 $\beta-511 \mathrm{~T}$ gene was $1.7-1.8$ times that in non-carriers [odds ratio $(\mathrm{OR})=1.742$ and $1.839, \mathrm{P}<0.05$ ]. In patients with abnormal HDL-C, the risk of disease in carriers with IL-1 $\beta-511 \mathrm{~T}$ gene was 2.0-2.2 times that in non-carriers
\end{abstract}

Correspondence to: Dr Qiang Meng, ICU Ward 2, Jining No. 1 People's Hospital, Jining Medical University, 6 Jiankang Road, Jining, Shandong 272100, P.R. China

E-mail:mf95ve@163.com

*Contributed equally

Key words: myocardial infarction, ischemic stroke, IL-1 $\beta-511 \mathrm{C} / \mathrm{T}$, gene polymorphism
(OR = 2.011 and 2.249, $\mathrm{P}<0.05)$. Besides, the risk of MI complicated with IS in carriers with $\mathrm{CC}$ genotype had no significant difference in patients with arrhythmia and abnormal HDL-C ( $\mathrm{P}>0.05)$. IL-1 $\beta-511 \mathrm{C} / \mathrm{T}$ gene polymorphism may be related to the risk of MI complicated with IS.

\section{Introduction}

Myocardial infarction (MI) is a severe cardiovascular disease, which is often accompanied with increased activity of serum myocardial enzyme and progressive changes in electrocardiograms (ECGs), and may lead to arrhythmia, shock and heart failure (1). Ischemic stroke (IS) is a common complication of MI (2), which can be caused by a variety of factors. The incidence rate of IS is high in the elderly, and the disease severely affects the prognosis of MI patients (3). MI patients complicated with IS have a significantly higher mortality rate than patients with MI alone $(4,5)$, which has attracted extensive attention in the clinic. Studies have shown that there are often abnormal ECG changes of patients with acute IS, and ECG changes of these patients are very sensitive with a very low specificity, suggesting that ECGs are insufficient to be used as a diagnostic criterion for IS (6). The major pathological basis of IS is atherosclerosis (7), and the relevant inflammatory response during atherosclerosis is mainly initiated jointly by interleukin (IL) and some other related factors $(8,9)$.

IL is an important pro-inflammatory factor playing an important role in ischemic brain injury $(10,11)$. It has been proved in studies that IL-1 gene polymorphism has a certain correlation with cerebral infarction $(12,13)$. IL-1 family members include IL- $1 \alpha$, IL-1 $\beta$ and IL-1Ra, the first two of which can be involved in the senescence of vascular endothelial cells and inflammatory response of hypoxic-ischemic brain injury, thereby affecting the function of vascular endothelial cells and atherosclerosis process (14). Studies have revealed that there is $\mathrm{C} / \mathrm{T}$ polymorphism in the IL-1 $\beta-511$ locus (15), which may be related to the occurrence of IS (16). This study investigated the correlation between IL-1 $\beta-511 \mathrm{C} / \mathrm{T}$ gene polymorphism and MI complicated with IS, so as to provide references for future research. 
Table I. Primer sequences of IL-1 $\beta-511 \mathrm{C} / \mathrm{T}$ amplification.

\begin{tabular}{llcl}
\hline SNP & Primer sequence (5'-3') & Fragment length (bp) & Tm value \\
\hline IL-1 $\beta-511 \mathrm{C} / \mathrm{T}$ & F: TGGCATTGATCTGGTTCATC & 304 & $58^{\circ} \mathrm{C}$ \\
& R: GTTTAGGAATCTTCCCACTT & \\
\hline
\end{tabular}

IL, interleukin; F, forward; R, reverse.

Table II. Enzyme digestion fragment length and genotyping.

\begin{tabular}{|c|c|c|c|c|c|c|c|}
\hline \multirow[b]{2}{*}{ SNP } & \multirow{2}{*}{$\begin{array}{c}\text { Enzyme } \\
\text { digestion } \\
\text { site }\end{array}$} & \multicolumn{6}{|c|}{ Enzyme digestion fragment (bp) } \\
\hline & & & $\mathrm{C}$ & & $\mathrm{CT}$ & & TT \\
\hline IL-1 $\beta-511 \mathrm{C} / \mathrm{T}$ & $A v a \mathrm{I}$ & 190 & 114 & 304 & 190 & 114 & 304 \\
\hline
\end{tabular}

IL, interleukin.

\section{Materials and methods}

General data. A total of $251 \mathrm{MI}$ patients treated in the People's Hospital of Zhangqiu District (Jinan, China) from September 2014 to October 2017 were selected as observation group, including 136 males and 115 females with an average age of $62.8 \pm 5.4$ years. The diagnostic criteria met the universal definition of MI in 2012. Patients with cerebral hemorrhage and space-occupying lesions were excluded. Another 200 healthy people receiving physical examination in People's Hospital of Zhangqiu District during the same period were selected as control group, including 101 males and 99 females with an average age of $61.2 \pm 6.8$ years, and they had no recent inflammation. The study was approved by the Ethics Committee of People's Hospital of Zhangqiu District. Patients who participated in this research, signed an informed consent and had complete clinical data.

\section{Research methods}

Main reagents. Wizard whole blood deoxyribonucleic acid (DNA) extraction kit, Taq DNA polymerase, polymerase chain reaction $(\mathrm{PCR})$ product purification and recycling kit, and restriction endonuclease NcoI were purchased from Sangon Biotech Co., Ltd. (Shanghai, China). Primers used in this study were all synthesized by Nanjing GenScript Biotechnology Corp. (Nanjing, China).

Specimen collection. After $2 \mathrm{ml}$ fasting venous blood was collected, and ethylene diamine tetraacetic acid (EDTA) was added for anticoagulation in accordance with instructions of the Wizard whole blood DNA extraction kit. A total of $300 \mu 1$ whole blood was added with $900 \mu \mathrm{l}$ cell lysis solution, shaken fully and mixed evenly, followed by incubation at room temperature for $5 \mathrm{~min}$ and centrifugation at $13,000 \mathrm{xg}$ at room temperature for $15 \mathrm{sec}$. Then the supernatant was discarded. The nuclear lysis solution was added and mixed evenly with the sediment, and the protein precipitation solution was added and mixed evenly, followed by centrifugation at 13,000 x g for $3 \mathrm{~min}$. The supernatant was transferred into a new centrifuge tube, and $30 \mu \mathrm{l}$ isopropanol was added to precipitate DNA. After centrifugation, the sediment was washed twice with $70 \%$ ethanol, and added with DNA dissolving solution to obtain the whole blood DNA.

IL-1 $\beta-511 C /$ T amplification. The PCR primers of IL-1 $\beta-511 \mathrm{C} / \mathrm{T}$ gene were designed according to the study of Li et al (17), and synthesized by Nanjing GenScript Biotechnology Corp. Primer sequences are shown in Table I. A total of $20 \mu 1$ PCR system included $2 \mu \mathrm{l}$ buffer, $2 \mu \mathrm{l}$ dNTPs, $0.5 \mu \mathrm{l}$ forward primers and $0.5 \mu \mathrm{l}$ reverse primers, $1 \mu \mathrm{l}$ Taq enzyme, $1 \mu \mathrm{l}$ DNA, and $20 \mu \mathrm{lddH_{2 }}$ O. PCR conditions are as follows: $95^{\circ} \mathrm{C}$ for $5 \mathrm{~min}$, $95^{\circ} \mathrm{C}$ for $50 \mathrm{sec}, 58^{\circ} \mathrm{C}$ for $50 \mathrm{sec}$, and $72^{\circ} \mathrm{C}$ for $1 \mathrm{~min}$ for a total of 30 cycles, and $72^{\circ} \mathrm{C}$ for $10 \mathrm{~min}$. According to instructions of the PCR product purification and recycling kit, the PCR products were purified and recycled for subsequent enzyme digestion assay.

Enzyme digestion reaction and genotype analysis. Enzyme digestion reaction was performed for the above-mentioned recycled PCR products. A total of $10 \mu \mathrm{l}$ enzyme digestion reaction systems included $1 \mu \mathrm{l}$ buffer, $1 \mu \mathrm{l}$ restriction endonuclease Ava I, and $8 \mu \mathrm{l}$ recycled PCR products. The reaction was performed at $37^{\circ} \mathrm{C}$ for $6 \mathrm{~h}$. The products after enzyme digestion were separated via $1.5 \%$ agarose gel electrophoresis. The product fragment size was detected by using the GeneSnap software of Syngene gel imaging system, based on which the different genotypes were determined. Each genotype was analyzed by using the fragment content (Table II).

Statistical analysis. Statistical Product and Service Solutions (SPSS) 17.0 (SPSS, Inc., Chicago, IL, USA) was used for statistical processing. Measurement data are presented as mean \pm standard deviation. t-test was used for the analysis between two groups, and Chi-square test was used for enumeration data. $\mathrm{P}<0.05$ was considered to indicate a statistically significant difference. The correlation between IL-1 $\beta-511 \mathrm{C} / \mathrm{T}$ and MI complicated with IS was detected via logistic regression analysis.

\section{Results}

Analysis of clinical data in both groups. All the participants of the study in both groups had complete clinical data (Tables III and IV). There were no significant differences in age, sex, history of hypertension and smoking history between the two groups ( $P>0.05)$, but the history of diabetes mellitus and arrhythmia had significant differences $(\mathrm{P}<0.05)$. 
Table III. Comparison of clinical data between the two groups.

\begin{tabular}{|c|c|c|c|c|c|c|c|}
\hline Groups & $\mathrm{n}$ & $\begin{array}{c}\text { Age } \\
\text { (years) }\end{array}$ & $\begin{array}{l}\text { Male } \\
\mathrm{n}(\%)\end{array}$ & $\begin{array}{c}\text { Hypertension } \\
\mathrm{n}(\%)\end{array}$ & $\begin{array}{c}\text { Diabetes mellitus } \\
\mathrm{n}(\%)\end{array}$ & $\begin{array}{l}\text { Smoking } \\
\mathrm{n}(\%)\end{array}$ & $\begin{array}{c}\text { Arrhythmia } \\
\text { n }(\%)\end{array}$ \\
\hline Control & 200 & $61.20 \pm 6.80$ & $101(50.50)$ & $113(56.50)$ & $30(15.00)$ & $62(31.00)$ & $5(2.50)$ \\
\hline Observation & 251 & $62.80 \pm 5.40$ & $136(54.20)$ & $140(55.80)$ & $71(28.30)$ & $76(30.30)$ & $176(70.10)$ \\
\hline$\chi^{2}$ & & 0.102 & 0.294 & 0.019 & 10.786 & 0.025 & 211.827 \\
\hline P-value & & 0.766 & 0.588 & 0.891 & 0.001 & 0.876 & $<0.001$ \\
\hline
\end{tabular}

Table IV. Comparison of blood routine and blood lipid data between the two groups (mean \pm SD).

\begin{tabular}{|c|c|c|c|c|c|c|c|c|c|c|}
\hline \multirow[b]{2}{*}{ Groups } & \multirow[b]{2}{*}{$\mathrm{n}$} & \multicolumn{5}{|c|}{ Blood routine $\left(10^{9} / 1\right)$} & \multicolumn{4}{|c|}{ Blood lipid (mmol/l) } \\
\hline & & RBC count & $\mathrm{Hb}(\mathrm{g} / \mathrm{l})$ & WBC count & NEU count & PLT count & HDL-C & LDL-C & $\mathrm{TC}$ & TG \\
\hline Control & 200 & $4.05 \pm 0.53$ & $115.54 \pm 18.85$ & $10.35 \pm 4.53$ & $8.03 \pm 4.85$ & $235.41 \pm 68.33$ & $1.45 \pm 0.25$ & $2.78 \pm 0.57$ & $4.78 \pm 0.83$ & $1.38 \pm 0.45$ \\
\hline Observation & 251 & $4.13 \pm 0.45$ & $110.36 \pm 15.48$ & $9.87 \pm 3.23$ & $7.59 \pm 2.89$ & $231.28 \pm 70.19$ & $1.32 \pm 0.21$ & $2.66 \pm 0.62$ & $4.59 \pm 0.92$ & $1.58 \pm 1.03$ \\
\hline t value & & 0.623 & 2.622 & 0.64 & 0.389 & 3.846 & 5.629 & 4.157 & 3.657 & -0.597 \\
\hline P-value & & 0.597 & 0.117 & 0.588 & 0.735 & 0.061 & 0.03 & 0.053 & 0.067 & 0.611 \\
\hline
\end{tabular}

RBC, red blood cell; Hb, hemoglobin; WBC, white blood cell; NEU, neutrophil; PLT, platelet; HDL-C, high-density lipoprotein cholesterol; LDL-C, low-density lipoprotein cholesterol; TC, total cholesterol; TG, triglyceride.

Table V. Comparison of IL-1 $\beta-511 \mathrm{C} / \mathrm{T}$ genotype and allele frequency between the two groups.

\begin{tabular}{|c|c|c|c|c|c|}
\hline \multirow[b]{2}{*}{ Groups } & \multicolumn{3}{|c|}{ Genotype frequency, n (\%) } & \multicolumn{2}{|c|}{ Allele frequency, n (\%) } \\
\hline & $\mathrm{CC}$ & $\mathrm{CT}$ & TT & $\mathrm{C}$ & $\mathrm{T}$ \\
\hline Control $(n=200)$ & $143(71.50)$ & $37(18.50)$ & $20(10.00)$ & $323(80.75)$ & $77(19.25)$ \\
\hline Observation $(n=251)$ & $134(53.39)$ & $80(31.87)$ & $37(14.70)$ & $348(69.30)$ & $154(30.68)$ \\
\hline$\chi^{2}$ & \multicolumn{3}{|c|}{15.598} & \multicolumn{2}{|c|}{15.259} \\
\hline P-value & \multicolumn{3}{|c|}{$<0.001$} & \multicolumn{2}{|c|}{$<0.001$} \\
\hline
\end{tabular}

IL, interleukin.

Table VI. Logistic regression analysis of risk factors of MI complicated with IS.

\begin{tabular}{lccc}
\hline Factor & OR & $(95 \% \mathrm{CI})$ & P-value \\
\hline Diabetes mellitus & 1.038 & $0.997-1.031$ & 0.192 \\
Arrhythmia & 0.147 & $0.027-0.337$ & 0.026 \\
HDL-C & 1.231 & $1.067-2.358$ & 0.031
\end{tabular}

MI, myocardial infarction; OR, odds ratio; HDL-C, high-density lipoprotein cholesterol; CI, confidence interval.

No significant differences were found in the blood routine examination at admission between the two groups $(\mathrm{P}>0.05)$. In blood lipid indexes, there was a significant difference in the high-density lipoprotein cholesterol (HDL-C) level between the two groups $(\mathrm{P}<0.05)$, and the level was obviously lower in the observation group than that in the control group. Other indexes had no significant differences $(\mathrm{P}>0.05)$.

Analysis of IL-1 $\beta-511 C / T$ gene polymorphism in two groups. IL-1 $\beta-511 \mathrm{C} / \mathrm{T}$ genotype distribution and allele frequency were significantly different between the observation and the control groups $(\mathrm{P}<0.05)$ (Table V). CT and TT genotype frequencies in the observation group were all higher than those in the control group. The frequency of $\mathrm{T}$ allele in the observation was remarkably higher than that in the control group, but the frequency of $\mathrm{C}$ allele was obviously lower than that in the control group.

Results of multivariate logistic regression analysis. The correlations of diabetes mellitus, arrhythmia and HDL-C with MI complicated with IS were analyzed via logistic regression analysis. It was found that arrhythmia and HDL-C were related to MI complicated with IS $(\mathrm{P}<0.05)$ (Table VI). The effect of IL-1 $3-511 \mathrm{C} / \mathrm{T}$ gene polymorphism on MI complicated with IS 
Table VII. Logistic regression analysis of IL-1 $\beta-511$ locus.

\begin{tabular}{|c|c|c|c|c|c|c|c|c|}
\hline \multirow[b]{2}{*}{ IL-1 $\beta-511$ genotype } & \multicolumn{4}{|c|}{ Arrhythmia } & \multicolumn{4}{|c|}{ HDL-C } \\
\hline & $\mathrm{n}$ & OR & $95 \% \mathrm{CI}$ & P-value & $\mathrm{n}$ & OR & $95 \% \mathrm{CI}$ & P-value \\
\hline $\mathrm{CC}$ & 59 & 1.213 & $0.519-2.304$ & 0.651 & 51 & 0.874 & $0.484-1.852$ & 0.752 \\
\hline $\mathrm{CT}$ & 80 & 1.742 & $1.036-2.029$ & 0.029 & 89 & 2.011 & $1.062-2.353$ & 0.009 \\
\hline TT & 37 & 1.839 & $1.098-2.249$ & 0.017 & 43 & 2.249 & $1.634-2.548$ & $<0.001$ \\
\hline
\end{tabular}

IL, interleukin; HDL-C, high-density lipoprotein cholesterol; OR, odds ratio; CI, confidence interval.

was analyzed. Results of logistic regression analysis (Table VII) showed that in patients with arrhythmia, the risk of disease in carriers of IL-1 $\beta-511 \mathrm{~T}$ gene $(\mathrm{n}=117)$ was $1.7-1.8$ times that in non-carriers $(\mathrm{n}=59)$ [odds ratio $(\mathrm{OR})=1.742$ and 1.839 , $\mathrm{P}<0.05]$. In patients with abnormal HDL-C, the risk of disease in carriers of IL-1 $\beta-511 \mathrm{~T}$ gene $(n=132)$ was 2.0-2.2 times that in non-carriers $(\mathrm{n}=51)(\mathrm{OR}=2.011$ and 2.249, $\mathrm{P}<0.05)$. Besides, the risk of MI complicated with IS in carriers of CC genotype had no significant difference in patients with arrhythmia and abnormal HDL-C $(\mathrm{P}>0.05)$.

\section{Discussion}

As a common complication of MI, IS has different pathogenesis and complex and diversified symptoms, bringing difficulties to clinical prediction (18). The main reason for MI complicated with IS is cardiogenic cerebral embolism, which occurs more easily in patients accompanied with atrial arrhythmia or intracardiac mural thrombus. Besides, hypotension, reflex cerebral arterial spasm, and simultaneous thrombosis in cerebral artery and coronary artery are also important causes of MI complicated with IS (19).

IL can act on multiple systems in the body, which possesses extensive biological effects and can mediate inflammatory reactions and participate in immune regulation, lipid metabolism and other physiological processes (20). In the IL-1 family, IL- $1 \alpha$ and IL- $1 \beta$, through inhibiting the endothelial cell proliferation, can induce the expression of adhesion molecules, lead to aggregation of monocytes and lymphocytes, promote thrombosis, and accelerate the formation of atherosclerosis (21). IL plays an important role in IS. Studies have manifested that there are polymorphisms in the IL- $1 \alpha-889-\mathrm{C} / \mathrm{T}$ and IL-1 $\beta-511 \mathrm{C} / \mathrm{T}$ loci, which have been found to be able to affect the activity of IL-1, and change the occurrence and development of hypertension and coronary heart disease, by affecting the inflammatory response (22). In this study, results revealed that both $\mathrm{IL}-1 \beta-511 \mathrm{C} / \mathrm{T}$ genotype distribution and allele frequency were significantly different between the observation and the control groups $(\mathrm{P}<0.05)$. The frequencies of CT genotype and TT genotype in the observation were higher than those in the control group, and the frequency of $\mathrm{T}$ allele in the observation was significantly higher than that in the control group $(\mathrm{P}<0.05)$, which were consistent with results obtained previously (23). According to results of logistic regression analysis, arrhythmia and HDL-C were associated with MI complicated with IS. In patients with arrhythmia, the risk of disease in carriers with IL-1 $\beta-511 \mathrm{~T}$ gene was 1.7-1.8 times that in non-carriers $(\mathrm{OR}=1.742$ and $1.839, \mathrm{P}<0.05)$. In patients with abnormal HDL-C, the risk of disease in carriers with IL-1 $\beta-511 \mathrm{~T}$ gene was 2.0-2.2 times that in non-carriers $(\mathrm{OR}=2.011$ and 2.249, $\mathrm{P}<0.05)$. Besides, the risk of MI complicated with IS in carriers with CC genotype had no significant difference in patients with arrhythmia and abnormal HDL-C ( $\mathrm{P}>0.05)$. The above results indicate that the MI complicated with IS is related to the increase of IL-1 $\beta-511$ T allele frequency. IL-1 $\beta-511 \mathrm{~T}$ may indirectly affect the occurrence of IS through affecting arrhythmia and HDL-C content. However, some studies also argued that there is no correlation between IL-1 $\beta-511 \mathrm{C} / \mathrm{T}$ polymorphism and IS (24), which may be related to the sample size, regional differences and dynamic development of disease. In addition, the precipitating factors of MI may be different from those of stroke caused by other factors, thus leading to differences in results.

In conclusion, results of this study suggest that the IL- $1 \beta-511 \mathrm{C} / \mathrm{T}$ gene polymorphism may be involved in the occurrence and development of MI complicated with IS. However, clinical cases in only one region were observed in this experimental study, which had certain limitations, so studies involving more regions are needed to confirm the conclusion. Moreover, this study broadens thoughts for the research on MI complicated with IS at the level of gene polymorphism, and provides more possibilities for the prediction and treatment of MI complicated with IS.

\section{Acknowledgements}

Not applicable.

\section{Funding}

No funding was received.

\section{Availability of data and materials}

The datasets used and/or analyzed during the present study are available from the corresponding author on reasonable request.

\section{Authors' contributions}

LC and FL wrote this manuscript and collected specimen. LL and LY were responsible for PCR. ZW, JZ and QM contributed 
to enzyme digestion reaction and genotype analysis. All authors read and approved the final study.

\section{Ethics approval and consent to participate}

The study was approved by the Ethics Committee of People's Hospital of Zhangqiu District (Jinan, China). Patients who participated in this research had complete clinical data. Signed informed consents were obtained from the patients or the guardians.

\section{Patient consent for publication}

Not applicable.

\section{Competing interests}

The authors declare that they have no competing interests.

\section{References}

1. Thygesen K, Alpert JS, Jaffe AS, Simoons ML, Chaitman BR, White HD, Thygesen K, Alpert JS, White HD, Jaffe AS, et al Writing Group on the Joint ESC/ACCF/AHA/WHF Task Force for the Universal Definition of Myocardial Infarction; ESC Committee for Practice Guidelines (CPG): Third universal definition of myocardial infarction. Eur Heart J 33: 2551-2567, 2012.

2. Yang CJ, Chen PC, Lin CS, Tsai CL and Tsai SH: Thrombolytic therapy-associated acute myocardial infarction in patients with acute ischemic stroke: A treatment dilemma. Am J Emerg Med 35: 804.e1-804.e3, 2017.

3. Ariza-Sole A, Alegre O, Elola FJ, Fernandez C, Formiga F, Martinez-Selles M, Bernal JL, Segura JV, Iniguez A, Bertomeu V, et al: Management of myocardial infarction in the elderly. Insights from Spanish Minimum Basic Data Set. Eur Heart J Acute Cardiovasc Care: July 1, 2017 (Epub ahead of print).

4. Kuster GW, Baruzzi AC, Pacheco EP, Domingues RB, Pieruccetti M, Giacon LM, Garcia JC, Furlan V and Massaro AR: Early reperfusion therapy in acute ischemic stroke after recent myocardial infarction. Arq Neuropsiquiatr 74: 690-691, 2016.

5. Widimsky P, Coram R and Abou-Chebl A: Reperfusion therapy of acute ischaemic stroke and acute myocardial infarction: Similarities and differences. Eur Heart J 35: 147-155, 2014.

6. Zerna C, Hegedus J and Hill MD: Evolving treatments for acute ischemic stroke. Circ Res 118: 1425-1442, 2016.

7. Fan $\mathrm{J}$ and Watanabe T: Inflammatory reactions in the pathogenesis of atherosclerosis. J Atheroscler Thromb 10: 63-71, 2003.

8. Dewberry R, Holden H, Crossman D and Francis S: Interleukin-1 receptor antagonist expression in human endothelial cells and atherosclerosis. Arterioscler Thromb Vasc Biol 20: 2394-2400, 2000.

9. Akita K, Isoda K, Sato-Okabayashi Y, Kadoguchi T, Kitamura K, Ohtomo F, Shimada K and Daida H: An interleukin-6 receptor antibody suppresses atherosclerosis in atherogenic mice. Front Cardiovase Med 4: 84, 2017.

10. Boutin H, LeFeuvre RA, Horai R, Asano M, Iwakura Y and Rothwell NJ: Role of IL- $1 \alpha$ and IL-1 $\beta$ in ischemic brain damage. J Neurosci 21: 5528-5534, 2001.
11. Sordillo PP, Sordillo LA and Helson L: Bifunctional role of pro-inflammatory cytokines after traumatic brain injury. Brain Inj 30: 1043-1053, 2016.

12. Katakami N, Kaneto H, Osonoi T, Kawai K, Ishibashi F, Imamura K, Maegawa H, Kashiwagi A, Watada H, Kawamori R, et al: Transforming growth factor beta1 T868C gene polymorphism is associated with cerebral infarction in Japanese patients with type 2 diabetes. Diabetes Res Clin Pract 94: e57-60, 2011.

13. Fan N, Wang J, Deng Y, Zhu J, Mei J, Chen Y and Yang H: Association between genetic polymorphisms of interleukins and cerebral infarction risk: a meta-analysis. Biosci Rep 36: e00404, 2016. doi: 10.1042/BSR20160226.

14. Mariotti M, Castiglioni S, Bernardini D and Maier JA: Interleukin 1 alpha is a marker of endothelial cellular senescent. Immun Ageing 3: 4, 2006.

15. Slowik A, Borratynska A, Turaj W, Pera J, Dziedzic T, Wloch D, Szczudlik A, Betlej M, Krzyszkowski T and Czepko R: Interleukin 1beta-511 C/T polymorphism and risk of aneurysmal subarachnoid haemorrhage. J Neurol Neurosurg Psychiatry 77: 279-280, 2006.

16. Um JY, Moon KS, Lee KM, Yun JM, Cho KH, Moon BS and Kim HM: Association of interleukin-1 alpha gene polymorphism with cerebral infarction. Brain Res Mol Brain Res 115: 50-54, 2003.

17. Li N, He Z, Xu J, Liu F, Deng S and Zhang H: Association of PDE4D and IL-1 gene polymorphism with ischemic stroke in a Han Chinese population. Brain Res Bull 81: 38-42, 2010.

18. Ulvenstam A, Kajermo U, Modica A, Jernberg T, Söderström L and Mooe T: Incidence, trends, and predictors of ischemic stroke 1 year after an acute myocardial infarction. Stroke 45: 3263-3268, 2014.

19. Hosomi N, Yoshimoto T, Kanaya Y, Neshige S, Hara N, Himeno T, Kono R, Takeshima S, Takamatsu K, Ota T, et al: Brain natriuretic peptide and particular left ventricle segment asynergy associated with cardioembolic stroke from old myocardial infarction. J Stroke Cerebrovasc Dis 25: 1165-1171, 2016.

20. Lust JA, Lacy MQ, Zeldenrust SR, Dispenzieri A, Gertz MA, Witzig TE, Kumar S, Hayman SR, Russell SJ, Buadi FK, et al: Induction of a chronic disease state in patients with smoldering or indolent multiple myeloma by targeting interleukin 1 beta\}-induced interleukin 6 production and the myeloma proliferative component. Mayo Clin Proc 84: 114-122, 2009.

21. Dominici R, Cattaneo M, Malferrari G, Archi D, Mariani C, Grimaldi LM and Biunno I: Cloning and functional analysis of the allelic polymorphism in the transcription regulatory region of interleukin-1 alpha. Immunogenetics 54: 82-86, 2002.

22. Vohnout B, Di Castelnuovo A, Trotta R, D'Orazi A, Panniteri G, Montali A, Donati MB, Arca M and Iacoviello L: Interleukin-1 gene cluster polymorphisms and risk of coronary artery disease. Haematologica 88: 54-60, 2003.

23. Shiotani A, Sakakibara T, Nomura M, Yamanaka Y, Nishi R, Imamura $\mathrm{H}$, Tarumi $\mathrm{K}$, Kamada $\mathrm{T}$, Hata $\mathrm{J}$ and Haruma $\mathrm{K}$ : Aspirin-induced peptic ulcer and genetic polymorphisms. J Gastroenterol Hepatol 25 (Suppl 1): S31-S34, 2010.

24. Dziedzic T, Slowik A, Pera J and Szczudlik A: Lack of association between interleukin-1 $\beta$ polymorphism (-511) and ischaemic stroke. J Neurol Neurosurg Psychiatry 75: 170-171, 2004.

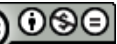

This work is licensed under a Creative Commons Attribution-NonCommercial-NoDerivatives 4.0 International (CC BY-NC-ND 4.0) License. 